\title{
Mapping fire regimes across time and space: Understanding coarse and fine-scale fire patterns
}

\author{
Penelope Morgan ${ }^{\mathrm{A}}$, Colin C. Hardy ${ }^{\mathrm{B}}$, Thomas W. Swetnam ${ }^{\mathrm{C}}$, Matthew G. Rollins ${ }^{\mathrm{B}}$ \\ and Donald G. Long ${ }^{\mathrm{B}}$
}

${ }^{A}$ University of Idaho, Department of Forest Resources, College of Natural Resources, Moscow, ID 83844-1133, USA. Telephone: +1 208885 7507; fax: +1 208885 6226; email: pmorgan@uidaho.edu

${ }^{B} U S D A$ Forest Service, Rocky Mountain Research Station, Fire Sciences Laboratory, PO Box 8089, Missoula, MT 59807, USA. Telephone: +1 406329 4978; fax: +1 406329 4877; email: chardy01@fs.fed.us; mrollins@fs.fed.us; dlong@fs.fed.us ${ }^{\mathrm{C}}$ University of Arizona, Laboratory of Tree-Ring Research, Tucson, AZ 85721, USA. Telephone: +1 520621 2112; fax: +1 520621 8229; email: tswetnam@ltrr.arizona.edu

This paper was presented at the conference 'Integrating spatial technologies and ecological principles for a new age in fire management', Boise, Idaho, USA, June 1999

\begin{abstract}
Maps of fire frequency, severity, size, and pattern are useful for strategically planning fire and natural resource management, assessing risk and ecological conditions, illustrating change in disturbance regimes through time, identifying knowledge gaps, and learning how climate, topography, vegetation, and land use influence fire regimes. We review and compare alternative data sources and approaches for mapping fire regimes at national, regional, and local spatial scales. Fire regimes, defined here as the nature of fires occurring over an extended period of time, are closely related to local site productivity and topography, but climate variability entrains fire regimes at regional to national scales. In response to fire exclusion policies, land use, and invasion of exotic plants over the last century, fire regimes have changed greatly, especially in dry forests, woodlands, and grasslands. Comparing among and within geographic regions, and across time, is a powerful way to understand the factors determining and constraining fire patterns. Assembling spatial databases of fire information using consistent protocols and standards will aid comparison between studies, and speed and strengthen analyses. Combining multiple types of data will increase the power and reliability of interpretations. Testing hypotheses about relationships between fire, climate, vegetation, land use, and topography will help to identify what determines fire regimes at multiple scales.
\end{abstract}

\section{Introduction}

Fire is a dominant disturbance in many wildland ecosystems worldwide. Because fire influences the structure, composition, and function of ecosystems, maps of fire regimes (fire frequency, severity, size, pattern etc.) are useful for planning, assessing risk, and evaluating ecological conditions. Mapped data provide understanding of how spatial processes like climate, topography, and vegetation dynamics influence fire regimes. Fire regime refers to the 'nature of fires occurring over an extended period of time' (Brown 1995). Fire regimes reflect the fire environment, and influence the type and abundance of fuel, thereby affecting fire behavior and fire effects through time.

Fire regimes can be described by frequency, magnitude (severity and intensity), predictability, size, seasonality, and spatial patterns (Heinselman 1981; Pickett and White 1985; Agee 1993; Crutzen and Goldammer 1993). The frequency of fires, expressed as fire return interval, probability of occurrence, or rotation period, is the number of fire events at a point (point frequency) or within a specified area (area frequency or rotation period) and a time period, or period of record. Point fire frequencies, like mean fire interval (Heinselman 1973; Agee 1993) or Wiebull mean fire interval (Johnson 1992; Finney 1995; Grissino-Meyer 1999) are explicitly spatial, but represent spatial patterns as aggregates of point samples. Fire rotation period and fire cycle, on the other hand, incorporate reconstructed or mapped fire perimeters, and are defined as the length of time necessary to burn an area equivalent to a specific study area or landscape (Heinselman 1973; Agee 1993; Johnson and Gutsell 1994). Fire cycle is distinguished from fire rotation 
in that it is calculated based on the distribution of ages in a time-since-fire map (Johnson and Larson 1991; Johnson and Gutsell 1994). Fire cycle and fire rotation period incorporate both the extent and frequency of fires. This is the main distinction between fire regimes described using mean fire frequencies and fire rotation periods. The frequency of fires directly and indirectly affects species life cycles, vegetation structure and composition, and fuel accumulation and is the main theme of much research involving the evaluation of fire regimes.

Fire intensity and severity describe the behavior and effects of individual fires. Fire intensity is a physical description of fire behavior, and is defined as the amount of energy released by a flaming front. Fire intensity is closely correlated with flame length (Albini 1976). Fire severity is broadly defined as the degree of ecosystem change induced by fire (Ryan and Noste 1985). Fire severity has been described by the degree of tree mortality (Agee 1993; Morgan et al. 1996), heat penetrating into the soil (Lea and Morgan 1993), degree to which fires consume organic biomass on and within the soil (Lenihan et al. 1998), change in color of ash and soil (Wells et al. 1979; Ryan and Noste 1985), or a combination of these fire effects (Turner et al. 1994). Biomass consumption and soil heating influence post-fire carbon and nitrogen cycles (Lenihan et al. 1998) and vegetation response patterns (Morgan and Neuenschwander 1988; Lea and Morgan 1993; Ryan and Noste 1985), but may be poorly correlated with overstory vegetation mortality. Fire frequency and severity are most often used to classify and map fire regimes (Heinselman 1973, 1978, 1981; Morgan et al. 1996; Hardy et al. 1998a, 1998b, 1999; Brown and Smith 2000). For mapping fire regimes, severity is typically defined based upon degree of mortality in overstory vegetation-even where the dominant overstory is shrubs (in shrublands) or grasses (in grasslands).

Fire regime descriptors change depending on the spatial or temporal scale at which they are measured. For instance, fire frequency varies whether it is calculated from data aggregated for individual trees, tree clusters, or stands (Arno and Peterson 1983). The scale at which data are collected, analysed and mapped defines fire regime and the utility of the resulting map. Scale issues include the temporal and spatial extent and resolution of data used to define fire regimes, as well as the number of classes mapped (i.e. the thematic or floristic resolution). The coarse scale $\left(1 \mathrm{~km}^{2}\right)$ fire regime maps for the Interior Columbia River Basin (Morgan et al. 1996) and the conterminous U.S. (Hardy et al. 1998a, $1998 b, 1999)$ are useful for strategic, programmatic planning, but are of limited utility for local applications, except to provide broad context.

Understanding fire regimes across temporal scales of seasons to years to decades and centuries, and spatial scales from a single patch or stand, to regions, nations, and continents is inherently challenging for several reasons. Fire is a stochastic, spatially complex disturbance process (Pickett and White 1985; Baker 1995), yet the data for describing fire regimes are typically collected at points or from small areas, and often from relatively short time series. Extrapolation of interpretations from empirically derived fire regimes is difficult and long-term predictions of burned area are often inaccurate (McKenzie et al. 1996b; Keane and Long 1998). Additionally, our interpretations of fire frequency are often biased by truncated time series (Finney 1995), which causes us to overestimate fire frequency.

Climate, vegetation, and topography all interact with fire and vary over space in complex ways that are not fully understood. Furthermore, vegetation and fire characteristics are often a legacy of both immediate and past events (i.e. they are temporally autocorrelated). The direct and indirect effects of fires on ecosystems vary across temporal and spatial scales. It is difficult to generalize the effects of fire in ecosystems because it is difficult to precisely evaluate either immediate or lagged fire effects at broad temporal and spatial extents (Crutzen and Goldammer 1993). Often, stochastic or mechanistic modeling is the only alternative for characterizing and assessing the variability of fire effects under different fire regimes (Keane and Long 1998). Fire and fire effects are inherently variable and heterogeneous, complicating the search for underlying cause and inferences about fire patterns over space and time (Lertzman et al. 1998). Fire regimes are not static. Fire regimes that are entrained by climate will change as climate varies. Definitions of fire regimes must explicitly incorporate the era from which fire regime data are used.

Understanding what determines fire regimes is important for both fuels management and for scientific reasons. Regional fire events have been a recurrent phenomenon across the western United States over many centuries. These extensive, extreme events were typically associated with droughts of corresponding spatial extent (Swetnam and Betancourt 1990, 1998; Swetnam 1993). In the 20th century, fire-fighting resources were stretched thin during these events (e.g. 1956, 1971, 1973, 1974, 1988, 1989, 1994, 2000), allowing some fires to achieve enormous sizes and intensities. Many of these conflagrations defied all fire fighting efforts and burned until fuels or weather limited them. Fire scientists must begin to assess the climatic causes of large, severe fire events. Such events often account for a majority of the total area burned over time (Strauss et al. 1989) and resource losses, as well as threats to people and their property (Maciliwain 1994). It is possible that as climate changes and fuels accumulate, severe fires may become more common.

In this paper, we review the state of the art of mapping fire regimes at national, regional, and local scales. A brief description of why people map fire regimes is followed by discussions of data sources. Then, different approaches to 
mapping are compared. Finally, we discuss what we've learned and future research needs.

\section{Why map fire regimes?}

Because fire regimes are a reflection of the fire environment, maps of fire regimes provide a broad context for resource management decisions, especially as they relate to fuels and fire management. Maps of historical and recent fire regimes (Morgan et al. 1996; Hardy et al. 1998a, 1998b 1999) have been included in broad ecological assessments and natural resource management planning efforts because managers find them useful for characterizing fire risk and identifying management opportunities. However, spatially explicit databases of fire regimes are more useful for broad-scale (regional or national) planning for fuels treatments than for tactical decisions involving wildfire use or fire suppression.

Departures from historical or presettlement fire regimes have been used to quantify ecosystem change (Brown et al. 1994; Skinner and Chang 1996; Quigley and Arbelbide 1997). Departures of one of more fire intervals from historical fire frequency have been used to identify areas of low ecological integrity (Quigley and Arbelbide 1997; Schmoldt et al. 1999), accumulating fuels and associated fire risk, and to prioritize for restoration. Contrasting past and present fire regimes can be useful in identifying where fire risks and hazards have changed the most.

Landscape managers find maps of historical fire regimes useful as a reference or baseline for understanding and evaluating ecosystem change (Morgan et al. 1994; Landres et al. 1999; Swetnam et al. 1999). Hardy et al. (1998a, 1998b 1999) used the historical natural fire regime as a biophysical baseline for determining departure of contemporary fire regimes from pre-EuroAmerican fire regimes in the United States. Cissell et al. (1999) used historical fire regimes as the basis for silvicultural prescriptions for landscape management of forests in Oregon and found that this produced more extensive late successional forest, larger patches, and less edge than the static reserves and matrix prescribed under the Northwest Forest Plan. DeLong (1998) compared forest disturbance rates and patch sizes to those mandated by provincial policy in British Columbia to approximate natural fire regimes, as Hunter (1993) recommended for boreal forests. Although restoring historical fire regimes is sometimes the goal of management, historical fire regimes may be impossible to restore precisely given social goals, land use, changing climate, and the presence of exotic species, structures, or processes. Maps of fire regimes are also useful for parameterizing and validating ecosystem models (Keane and Long 1998), and for extrapolating point and other local information to a continuous map (Long 1998).

One of the greatest utilities for mapping fire regimes is synthesizing knowledge and identifying gaps in knowledge about fire patterns over time and space. For example, through mapping efforts, it became clear how little is known about mixed fire regimes. They are extensive, occurring on $16 \%$ historically and $30 \%$ currently of the Interior Columbia River Basin (Morgan et al. 1996), and 10\% historically of the conterminous United States (Hardy et al. 1998a, 1998b). Little fire history information is available for mixed fire regimes, and the vegetation mosaics that develop with mixed fire regimes are complex and often misunderstood (Agee 1998).

\section{Data for mapping fire regimes}

Diverse sources of data exist for mapping fire regime characteristics (Agee 1993). These include operational databases of fire occurrence, compilations of archival fire perimeter data, remote sensing of fire patterns, and paleoecological evidence of past fires (Minnich 1983; Clark 1988; Chou and Minnich 1990; Agee 1993; Swetnam 1993; Millspaugh and Whitlock 1995; Swetnam and Baisan 1996; Minnich and Chou 1997; Swetnam and Betancourt 1998; Rollins 2000; Rollins et al. 2001). Information on historical fires may also be compiled through interviews, personal diaries, or literature searches. These latter data, while valuable, are largely anecdotal and spatially qualitative, and are not discussed further here. Fire history and vegetation changes have also been qualitatively and quantitatively inferred from land survey records (e.g. Wein and Moore 1979; Habeck 1994) and comparisons of old and recent pairs of photographs (Gruell et al. 1982), but these approaches are not discussed here.

Data for evaluating fire history vary in temporal and spatial resolution (Table 1), and in utility for describing different aspects of fire regimes. Each type of data has strengths and weaknesses for describing fire frequency, variability, season, severity, extent and location.

Much of the information on fire frequency comes from paleoecological data, such as charcoal in lake and soil sediments (e.g. Clark 1988, 1990; Millspaugh and Whitlock 1995) and wounds on the boles of trees caused by fires, or other dendroecological data such as stand ages. Basal scars on the boles of trees that result from non-lethal fires are an excellent source of information on past fires. Series of fire scars on a single tree or sets of trees can be precisely crossdated using tree ring analysis to reconstruct long time series of the year and sometimes the season of historical fires. The timing of stand-replacing fires that prompted establishment of new cohorts of trees can be inferred from the age structure of some forests. Such stand origin maps have most frequently been used to describe fire rotation (Heinselman 1973; Barrett et al. 1991; Agee 1993) and fire cycle (Johnson and Larson 1991; Johnson and Gutsell 1994). With the exception of stand origin maps, however, paleoecological data have limited utility for describing the spatial pattern of fires.

Networks of precisely dated fire-scar samples and sites have been used to estimate area burned based upon the 
Table 1. The data most commonly available for mapping fire regimes vary in spatial and temporal scale

\begin{tabular}{|c|c|c|c|c|}
\hline Data & Temporal scale & Spatial scale & Advantages & Disadvantages \\
\hline Atlases & 20th Century & Landscape & $\begin{array}{l}\text { Broad-scale, spatially explicit } \\
\text { perimeters }\end{array}$ & $\begin{array}{l}\text { Accuracy varies, only } \\
\text { includes perimeters }\end{array}$ \\
\hline $\begin{array}{l}\text { Time series of aerial } \\
\text { photographs }\end{array}$ & $\begin{array}{l}\text { Dependent upon photo } \\
\text { series availability }\end{array}$ & Landscape & $\begin{array}{l}\text { Extensive areas at high resolution, fire } \\
\text { perimeters and severity }\end{array}$ & $\begin{array}{l}\text { Photo availability, labor } \\
\text { intensive }\end{array}$ \\
\hline NIFMID (USDA 1998) & 1974-1997 & $\begin{array}{l}\text { Point data for } \\
\text { entire U.S. }\end{array}$ & All fires, extra information & $\begin{array}{l}\text { Point data, limited temporal } \\
\text { extent }\end{array}$ \\
\hline Dendroecological data & Multi-century & Point data & $\begin{array}{l}\text { Temporal extent, with annual and } \\
\text { sometimes seasonal precision }\end{array}$ & Point data, labor intensive \\
\hline
\end{tabular}

proportion of sites scarred in a given year (Swetnam 1993; Swetnam and Baisan 1996), as well as to identify and map fire episodes (Barrett et al. 1997). Regional-scale networks of dendroecological fire history information are now available for the western United States (Heyerdahl et al. 1995; Swetnam and Baisan 1996; Barrett et al. 1997). When they are carefully cross-dated, such data can also be used to assess spatial and climatic patterns across years, decades, and centuries.

Archival sources of information on fire extent and location include fire atlases, operational databases (such as individual fire reports), and photo-interpreted fire perimeters. Fire atlases are compilations of mapped fire perimeters maintained as hard-copy sets of maps or as GIS databases. Fire atlases include information on the date and perimeter of fires, but typically do not include information on fire severity, rate of spread, or perimeters of small fires (McKelvey and Busse 1996; Rollins 2000; Rollins et al. 2001). Fires represented in the fire atlases are, however, likely to represent a large proportion of area burned (Strauss et al. 1989; McKelvey and Busse 1996; Rollins 2000; Rollins et al. 2001). Although it can be difficult to find and obtain these as georeferenced records, the data are quite valuable where they are available. However, the errors in spatial location and date of fire occurrence are difficult to assess and can be severely limiting. Accuracy is unknown.

Fire perimeter locations and fire size can be interpreted from aerial photographs and satellite imagery (Minnich 1983). Green (1998) has interpreted the location, perimeter, and severity for 20th-century fires from time series of aerial photographs for the upper Selway River Basin in Idaho. Aerial photographs are one of the few sources of fire severity information other than detailed field sampling during or immediately after a fire. However, remote sensing from satellites has great potential for mapping post-fire tree mortality and severity (Turner et al. 1994; White et al. 1996), as well as lightning occurrence (Cummins et al. 1998). The National Interagency Fire Management Integrated Database (NIFMID) includes all fires by size class, location, and cause, but only for recent decades (USDA 1998). In NIFMID, fires are represented as points that represent the location, but not necessarily the ignition point, of individual fires. While NIFMID does not include spatial fire perimeter data, it does list fires of all sizes, and thus can complement fire atlases and other databases.

We have little empirical data that address both long time periods and broad spatial scales. Exceptions are the regional, multi-century fire history network for the Southwestern United States (Swetnam and Baisan 1996) and the data sets assembled by Rollins (2000) for the Gila/Aldo Leopold Wilderness Complex in New Mexico and the SelwayBitterroot Wilderness Complex in Idaho and Montana.

\section{Approaches to mapping and understanding fire regimes}

Mapping fire regimes necessitates extrapolating from the fine-scale study sites for which we have data on fire location, frequency, and severity to the broader landscape and regional scales at which we must address fuels and fire management and ecological questions. This process is challenging, especially in heterogeneous environments (McKenzie et al. 1996b; McKenzie 1998). A number of options exist.

\section{Rule-based}

The first option for extrapolating fire regime information from points or small areas to landscapes is to depend upon expert opinion using a rule-based approach. Using this approach, consistent, wall-to-wall maps can be developed relatively quickly, and the maps are readily revised as more information becomes available. Typically, rule-based maps are informed by, but not directly based upon, fire history data. This approach accommodates the minimal amount of information available on fire regimes in many vegetation types and geographical areas, but uncertainty is high where information is sparse or lacking. Typically, the classes used in fire regime mapping are relatively broad to reduce ambiguity. The resulting maps are usually coarse, with a spatial resolution of about $1 \mathrm{~km}^{2}$. These maps can effectively contrast past to current changes in fire regimes. Morgan et al. (1996) contrasted changes in fire regimes over the 20th century within the Columbia River Basin. Hardy et al. (1998a, 1998b , 1999) mapped historical fire regimes for the conterminous U.S. (Fig. 1). Rules were applied in a GIS to assign a fire regime class to combinations of vegetation or general land cover type interpreted from satellite data 


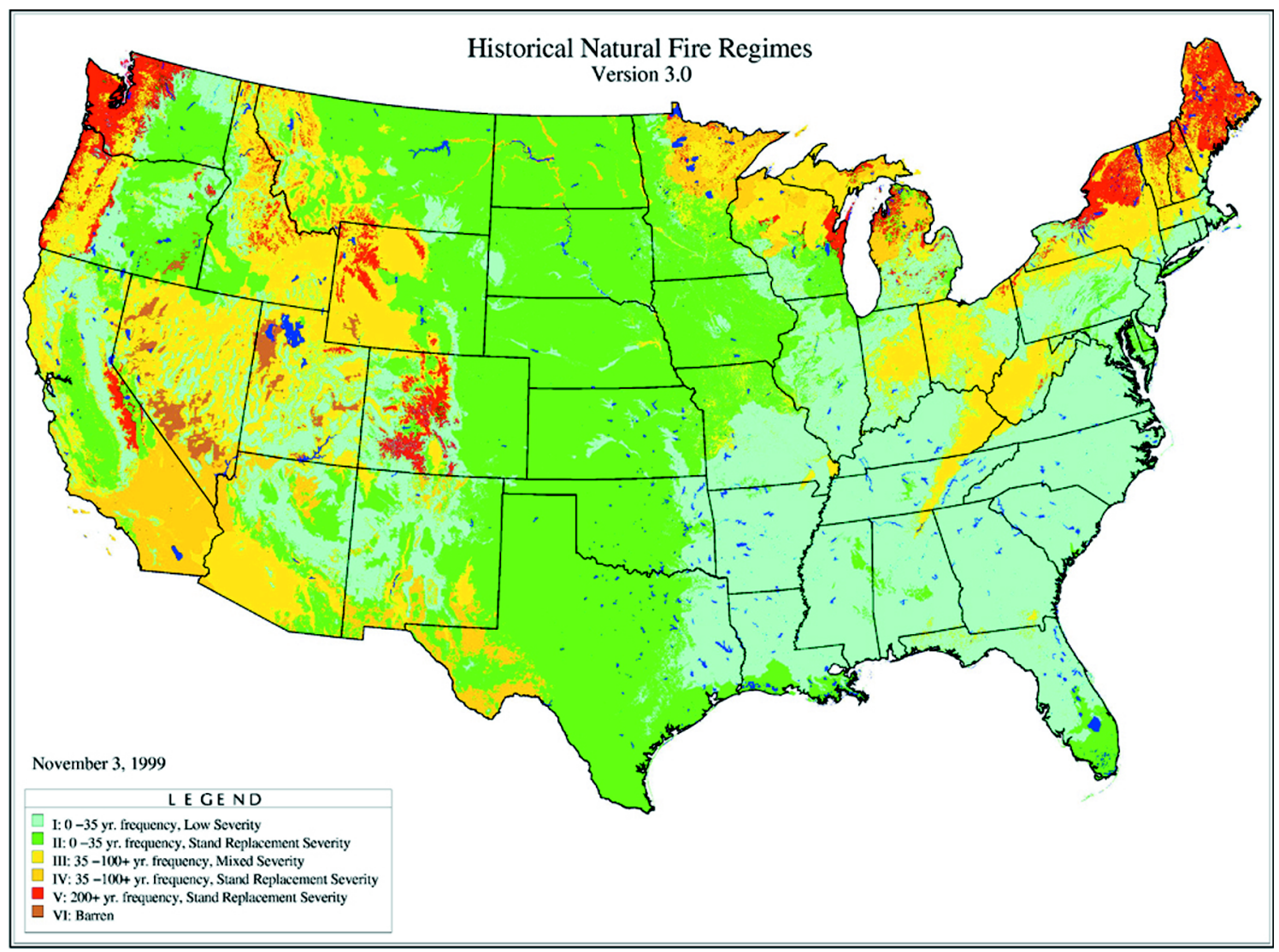

Fig. 1. Historical fire regimes mapped for the conterminous United States (Hardy et al. 1999).

(Loveland et al. 1991), potential vegetation type (Kuchler 1964), and ecoregions (Bailey 1995).

\section{Models}

The second option for extrapolating fine-scale information to broader scales is to use simulation (e.g. Keane and Long 1998; Miller and Urban 1999) or statistical models. Statistical models have been developed by McKenzie et al. (2000) for fire frequency in the Interior Columbia River Basin, Long (1998) for the Flathead National Forest, and D'Elia (1998) for semi-arid portions of the Great Basin. Models can be applied at regional to local scales; we present a local effort.

Long (1998) mapped historical (before 1935) fire regimes for the 1 million-ha Flathead National Forest in Montana (Fig. 2). Fire regime classes were assigned to 109 sample points based upon sampled fire-scar and tree age structure. Of 25 candidate variables, including physiography, climate, vegetation, fuels, and lightning ignitions, three variables produced the logistic regression models with the greatest predictive power: average annual precipitation, habitat type groups, and modified vegetation index. The logistic regression equations were used to produce probability GIS layers of fire regime classes, which were combined into one fire regime GIS layer for the entire Flathead National Forest (Fig. 2). The resulting map was validated using approximately 400 forest inventory sites, resulting in prediction accuracy from $60-90 \%$ in areas dominated by frequent fires of moderate severity and infrequent, standreplacing fires, and accuracy of $20-50 \%$ in areas dominated by frequent fires of moderate and low severity. These results suggest that extrapolation of fire regime classes from known points to unknown points is possible if the biophysical setting is known.

\section{Atlases}

Fire locations, frequency and sizes have been analysed from fire atlases (e.g. Minnich 1983; McKelvey and Busse 1996; Rollins 2000; Rollins et al. 2001). Cumulative area burned through time can be readily calculated from fire atlases, and fire patterns can be related to topography, vegetation, precipitation, other environmental and land use factors (McKelvey and Busse 1996; Rollins 2000), or fire suppression policies (Brown et al. 1994; Rollins 2000; Rollins et al. 2001). Unfortunately, the perimeters of fires mapped in fire atlases are often only approximate and the spatial pattern of burned areas within the mapped perimeters is seldom known. However, fire atlases allow spatial 


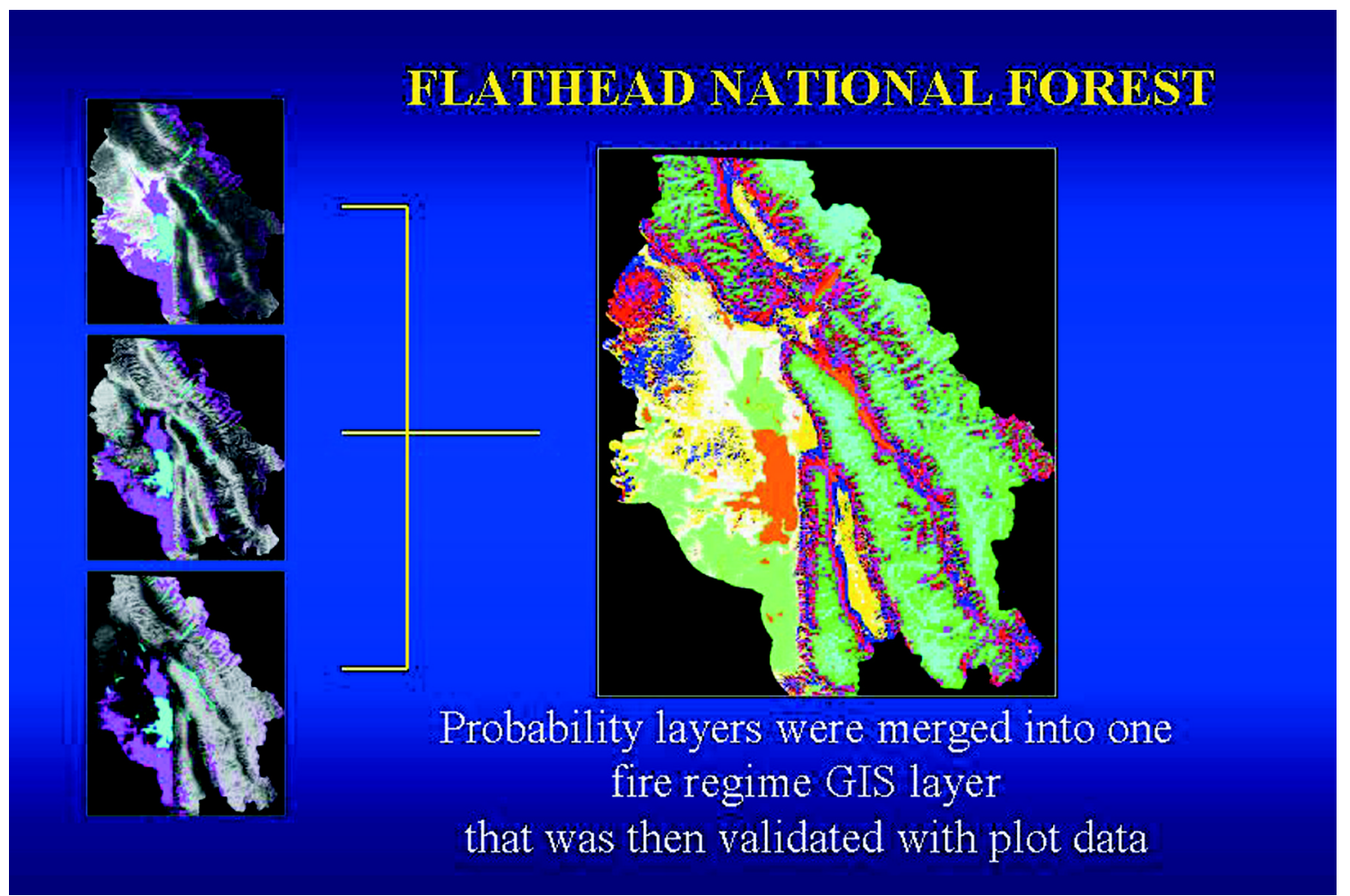

Fig. 2. Summary of historical fire regime classification process used for the Flathead National Forest (approximately 1 million ha) in Montana. Small maps to the left of the figure represent probability layers generated using logistic regression models to predict fire regime classes based upon physical environmental characteristics. Water and non-forest vegetation are shown in blue and magenta, respectively. Areas of higher probabilities of occurrence of each respective fire regime class are shown in brighter shades. Larger map to the right of the figure represents a classification of the three probability layers into seven discrete map units with characteristic mixes of each of the three fire regime classes.

analyses of fire location, fire size distribution, and 20th Century fire frequency, something often lacking from fire history research based on fire scars. Linking fire atlas data with fire occurrence data (e.g. NIFMID) to identify location of the smaller fires not mapped in the atlas enables a comprehensive spatial analysis of fires relative to topography, elevation, vegetation, and land use. Rollins et al. (2001) related fire frequency to elevation, potential vegetation type, and Palmer Drought Severity Index for the Gila/Aldo Leopold Wilderness Complex and the SelwayBitterroot Wilderness area. Although most of the area that burned within the 20th century did so within a few individual years, the area burned was influenced by elevation, drought and land use (including fire suppression policy and effectiveness). Ponderosa pine forests and warm, dry sites on steep slopes at middle elevations burned most frequently (Rollins 2000; Rollins et al. 2001).

\section{Fire scars}

Synchrony among well-dated fire scars from before the 20th century has been particularly important in understanding the fire climatology of regions and continents (Swetnam and
Betancourt 1990, 1998; Barrett et al. 1997; Veblen et al. 1999; Grissino-Mayer and Swetnam 2000). Years in which many trees were scarred by fire and extensive areas burned across a region have been compared to historical records of synoptic climate patterns (e.g. ocean-atmosphere teleconnections, such as El Niño-Southern Oscillation, Pacific Decadal Oscillation, and North Atlantic Oscillation, Fig. 3). The strengths of the fire-scar data are their extraordinary time depth-typically 300-500 years, and more than 2000 years in giant sequoia (Swetnam 1993) - and high temporal resolution - typically, fires are dated to the year, and often to the season of occurrence. Longer records include more extreme events, and patterns are sometimes apparent only when examining multiple examples of events that occur irregularly at multi-year to decadal intervals.

Very accurate dating, obtained through cross dating of treering patterns, makes it possible to meaningfully correlate fire events across spatial scales, and to compare the highly synchronized events (or asynchronous events) with independent temporal and spatial data. For example, independent tree-ring reconstructions of summer drought indices are now available for the entire conterminous U.S., back 

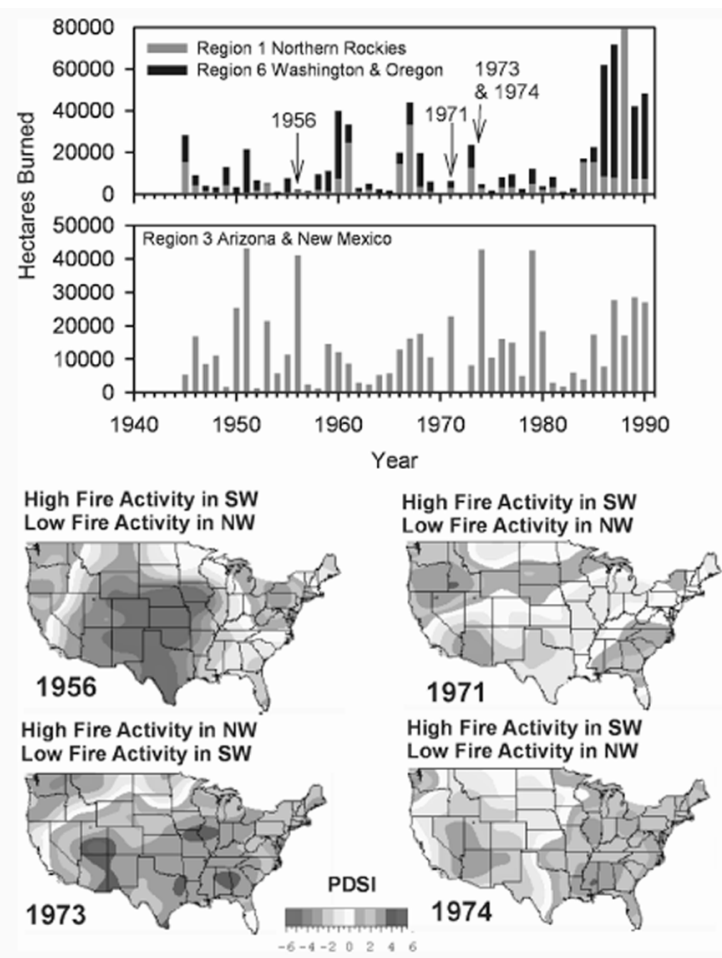

Fig. 3. The time series (upper graphs) show area burned on all National Forests in the Northern Rockies, Pacific Northwest, and Southwest Regions from 1900 to 1990 . Arrows show selected years of inverse fire activity in the northern regions versus the Southwest region. The maps shown below are the summer Palmer Drought Severity Indices (June-August) from a gridded set of meteorological station data (Cook et al. 1999).

at least to $1700 \mathrm{AD}$ (Cook et al. 1999), and these mapped patterns may be directly compared with regional and continental fire events reconstructed from fire scars. Year-to-year and decade-to-decade patterns (e.g. wet/dry lagging relations, and see also Veblen et al. 1999) in fire activity have been associated with drought and other climatic phenomena (Swetnam and Betancourt 1998; Grissino-Mayer and Swetnam 2000; Kitzberger et al. 2001). Understanding such climate-fire patterns is necessary for both long-range forecasting systems and for assessing forest responses to climate change.

\section{Combining approaches}

Combining different sources of data on fire history often overcomes some of the limitations of individual data sets. For instance, spatially explicit maps of the size and locations of both small and large fires can be produced through a combination of NIFMID and fire atlases; adding dated fire scars adds temporal depth. Rollins et al. (2001) spatially defined fire regimes based upon multiple data sets at different temporal and spatial scales for the Selway-Bitterroot and Gila/Aldo Leopold Wilderness areas (Fig. 4). Empirical models compared for the two areas are useful for elucidating which factors - regional climate, broad land-use policies, or local vegetation, topography and fuel conditions - are most important in determining fire regime characteristics and their locations across landscapes and regions (Rollins 2000).

\section{How do alternative approaches compare?}

We compared four different approaches for mapping historical fire regimes in the Interior Columbia River Basin area (Table 2). They include the (1) rule-based approaches of Hardy et al. (1998a, 1998b, 1999) and (2) rule-based approach of Morgan et al. (1996); (3) the vegetation succession modeling approach of Keane and Long (1998); and (4) the statistical modeling approach of McKenzie et al. (2000). We compared the percentage of the 80 million-ha area assigned to fire frequency and severity. The rule-based approaches were very similar (Table 2). Keane and Long (1998) estimated the greatest area of very infrequent and extremely infrequent fire regimes, while the statistical model of McKenzie et al. (2000) estimated the least amount of very infrequent and extremely infrequent classes. Percentage composition of fire severity classes show very comparable results between the rule-based approaches and the succession modeling approach; the latter predicts slightly higher amounts of non-lethal fire severity for the Interior Columbia River Basin.

\section{What we've learned}

We know much more about fire frequency than we do about fire size, severity, rotation, variability, and many other characteristics of fire regimes. We have made progress in relating fire frequency to climate, vegetation, and land use. Much of our information is limited to U.S. and Canada and to dry forests where non-lethal fire regimes predominated historically. Unfortunately, our limited knowledge will not allow accurate prediction of fire hazard or the analysis of trade-offs between alternative treatments. Accuracy and precision of fire history data are seldom quantified. Also, although the errors propagate when fire regime descriptors are derived from multiple data sets, the extent of these errors and ways to minimize them are seldom identified. Although seldom done until recently, examining the variability of fire regime characteristics over time and space is crucial if we are to understand the interplay between landscape patterns, climate, and fire.

Swetnam and Baisan (1996) reported the variance in mean fire interval relative to forest type and elevation. For grasslands, shrublands and woodlands, few fire history data exist, therefore few fire regime descriptions exist (but see Frost 1995, 1998; Conard and Wiese 1998; D'Elia 1998), mapping efforts are few, and they are done with less confidence. Wherever the location, combining multiple data sources is useful, and overcomes many of the weaknesses inherent in individual data sources. This is especially crucial if both spatial and temporal patterns are important.

Fire regimes are closely related to site productivity, to biophysical conditions, and to human influence. Only about 


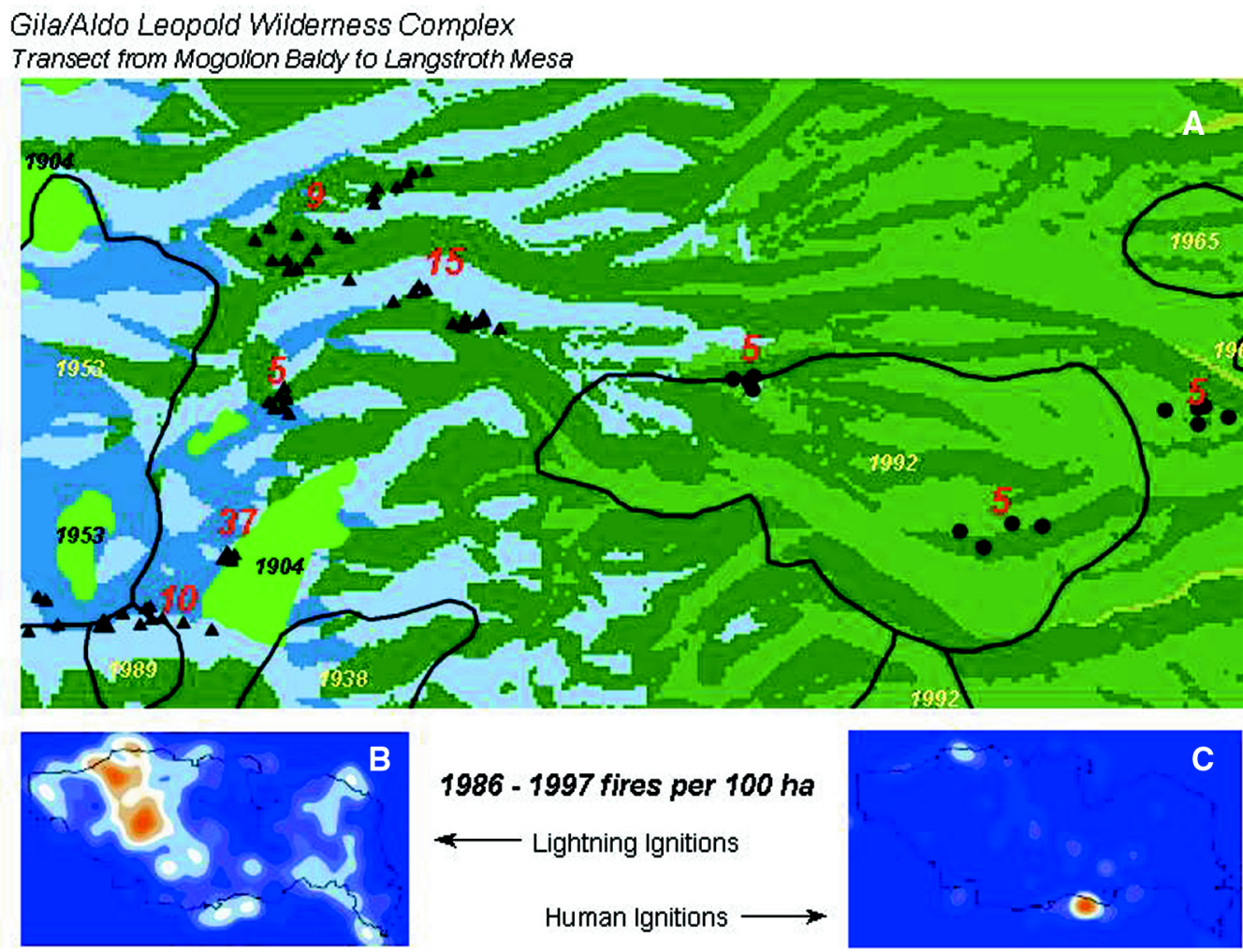

Fig. 4. Different sources of fire history data in the Gila/Aldo Leopold Wilderness Complex (Rollins et al. 1999). (A) The background is forest cover type with the year of stand origin indicated in yellow. Small black numbers and lines indicate the perimeter and year of fire occurrence from the fire atlas for the Gila National Forest. Triangles represent individual fire-scarred trees sampled for fire history. The large numbers written in red are the mean fire return intervals calculated at each site. $(B)$ and $(C)$ are numbers of lightning strikes and human-caused fires derived from NIFMID (USDA 1998). The boxes in $(C)$ and $(B)$ represent the spatial extent of $(A)$ relative to the study area boundary.

$1 \%$ of all fires account for $98 \%$ of the area burned (Strauss et al. 1989; Johnson and Wowchuck 1993). Extreme events are controlled by climate, especially severe drought (Johnson and Wowchuck 1993; Swetnam and Betancourt 1998). Fuels, topography, weather, humans, and biota are the major influences on fire occurrence, behavior, and effects in years when weather is not extreme. Mean fire intervals increased linearly with elevation in the Sierra (Swetnam et al. 1999), but fire frequency is often highest at middle elevations (McKelvey and Busse 1996; Rollins 2000; Rollins et al.

Table 2. A comparison of four approaches for mapping historical fire regimes for the Interior Columbia River Basin

The numbers are the percentage of the total 80 million-ha area assigned to a fire frequency or severity class. Severity class data were not available for McKenzie et al. (2000) study

\begin{tabular}{|c|c|c|c|c|}
\hline & $\begin{array}{c}\text { Hardy et al. } \\
(1998 a, 1998 b, 1999)\end{array}$ & $\begin{array}{l}\text { Morgan et al. } \\
\quad \text { (1996) }\end{array}$ & $\begin{array}{c}\text { Keane and Long } \\
\text { (1998) }\end{array}$ & $\begin{array}{l}\text { McKenzie } e t \\
\text { al. (2000) }\end{array}$ \\
\hline Fire frequency & \multicolumn{4}{|c|}{ Percentage of landscape } \\
\hline $0-25$ years & 39 & 33 & 24 & 33 \\
\hline $25-50$ years & 54 & 55 & 55 & 66 \\
\hline $300+$ years & 7 & 12 & 21 & 1 \\
\hline Fire severity & \multicolumn{4}{|c|}{ Percentage of landscape } \\
\hline Non-lethal & 39 & 44 & 33 & N/A \\
\hline Mixed & 32 & 34 & 44 & N/A \\
\hline Stand-replacing & 29 & 22 & 23 & N/A \\
\hline
\end{tabular}


2001). Over multiple centuries, more fires occurred there when the temperature was warmer, but year-to-year variations in moisture explained much of the annual variation in fire occurrence (Swetnam 1993). In the Southwest, the biggest fire years followed wet years (Swetnam and Betancourt 1998), but were varied by early, intense grazing by domestic livestock (Swetnam and Baisan 1996).

Little is known about spatial and temporal patterns of fire regimes in many forest types and geographic areas. Lack of data and inferences hinders efforts to assess the long-term consequences of fire management strategies that involve both wildfire use and fire suppression (Rollins 2000; Rollins et al. 2001). Fires create and are influenced by spatial pattern (Agee 1998). Mixed severity fire regimes, in particular, create complex mosaics of vegetation. Although it is likely that more extreme events are less influenced by topography and fire history, the interactions between broad-scale climatic factors and local site and vegetation conditions have been little studied.

Fire regimes are temporally and spatially autocorrelated (Clark 1989; Chou and Minnich 1990), which means that the probability of a given fire regime at one point is dependent, in part, on the fire regime on adjacent points. This happens because fires spread from one point to the next depending on adjacent fuel and topography and wind, and because the factors determining fire regimes, including topography, weather, vegetation, and land use, are themselves autocorrelated.

One of the climatic features controlling fire event synchrony within and between regions in the western U.S. is the position of the northern and southern branches of the jet stream. The resulting north-south contrast across the western U.S. (Dettinger et al. 1998) in the timing of droughts/wet periods and major fire years (see examples in Fig. 3) has important implications for anticipating and planning continental-scale fire fighting resources. Of course, jet stream patterns are not entirely predictable or consistent, nor are their regional impacts on fire regimes. Nevertheless, they clearly are an important component of broad-scale fire activity in the western U.S. and elsewhere (Simard et al. 1985; Kitzberger and Veblen 1997; Goldammer and Price 1998; Veblen et al. 1999).

Departures of current fire regimes from historical fire regimes are significant. Fires are currently less frequent on $57 \%$ and more severe on $24 \%$ of the 80 million-ha Interior Columbia River Basin in the Pacific Northwest (Morgan et al. 1996). Historically, $63 \%$ of the 640-million ha vegetated area of the conterminous U.S. experienced frequent fires (fires every 0-35 years, Hardy et al. 1998a, $1998 b, 1999)$. It is in the corresponding vegetation types, the dry forests (especially long-needled pines), grasslands, and woodlands, that fire regime has changed the most (Morgan et al. 1996), with corresponding alteration of vegetation structure, accumulating fuels, increasing fire risk, and declining ecological integrity (Covington and Moore 1994; Quigley and Arbelbide 1997). These vegetation types are the primary targets in the concern over forest and rangeland health. Although many innovative research and management strategies are focused on the dry forests, less attention has focused on the far more extensive grasslands, woodlands, and shrublands where fire regimes have also changed greatly with human influence.

\section{Future prospects and needs}

\section{Expanded definition of fire regimes}

There are no adequate spatial descriptors for fire regimes. No definition or descriptor of fire regime is independent of scale, but frequency data are especially scale-dependent (Arno and Peterson 1983; Simard 1991), while fires and fire effects are variable over both time and space. Fire regimes are defined for a particular time period, and for data with a particular spatial grain and extent. Variation over shorter time periods is 'noise', and long-term changes in fire regime interpreted from paleoecological studies or regional and national scales are 'context' (Lertzman et al. 1998). To be ecologically meaningful, the temporal scale should be chosen based upon life history of organisms affected (Clark et al. 1996); most often one to several times the life span of long-lived seral trees is used (Agee 1993; Lertzman et al. 1998). We often interpret longer-term variation in fire regime as change due to land use, climate, or other causes, but independent empirical data on those causal factors is necessary to differentiate real change in fire regimes from random variation (Lertzman et al. 1998). Random variation can generate complex, non-steady-state fire occurrence and age-class distribution even without change in the fire frequency or extent (Lertzman et al. 1998). It is difficult to find a statistically defensible definition of fire regime (Lertzman et al. 1998) for application across scales.

Variability and heterogeneity in fire regimes are seldom quantified. Yet they have profound implications for the ecological effects of fire, and our ability to infer and understand fire regimes themselves, especially over large areas and long times (Keane et al. 1990; McKenzie et al. 1996b; Lertzman et al. 1998; Schmoldt et al. 1999). Further, we must understand the three kinds of heterogeneity in fire regimes identified by Lertzman et al. (1998): internal heterogeneity of individual fires, and both the spatial and temporal heterogeneity of fire regimes. Variation in climate, ecological processes such as succession and disturbance, and ignition cause temporal heterogeneity (Lertzman et al. 1998). At times this variation is so great that fire regimes are best characterized by a mix of small, low severity and larger, high intensity fires (Heyerdahl 1997; Shinneman and Baker 1997). Heterogeneity is likely to vary substantially over both space and time, complicating sampling and interpretation of the ecological and management implications. Spatial heterogeneity of fuels and weather in space and time 
influences fire severity (Minnich 1983; McKenzie et al. 1996a; but see Keeley et al. 1999). Heterogeneity increases at broader spatial and temporal scales (Lertzman et al. 1998).

A quantitative, physical measurement of fire severity is needed that links the fire effects on structure with ecological process (Schmoldt et al. 1999). Without this, it is difficult to prescribe fire in ways appropriate for restoring fire as an ecological process, or for effectively evaluating where and what is needed in burn rehabilitation, e.g. to reduce soil erosion. Currently, maps of fire regimes are based on broad classes of overstory mortality (whether the dominant overstory is trees in forests and woodlands, shrubs in shrublands, or grass in grasslands). This crudely describes some of the ecological changes as a result of fire, but the effects of fire on carbon/nitrogen and other nutrient dynamics is not well represented. As a consequence, the ecosystem process models used to project the impact of changing climate on ecosystems are often neither linked to nor related to efforts to map and analyse changes in fire regimes. Lenihan et al. (1998) and Miller and Urban (1999) specifically incorporate fire severity into ecosystem process models that also account for environmental heterogeneity.

\section{Consistent data collection and storage}

Spatial databases of fire information need to be assembled with consistent protocols and standards to provide structure and format. These would aid comparison and speed and strengthen analysis. Many historical data sets are still in file cabinets; many are being lost. Hardy et al. (1998a, $1998 b, 1999)$ have assembled a database of fire occurrence for all Federal and State lands for 1986-1996. Most fire history databases cover short time periods and small geographic areas. Schmoldt et al. (1999) called for effectively integrating these regionally and nationally. Further, it is critical to locate, sample, and analyse the fire disturbance records on the landscape and in archival records. Old trees, stumps, and logs with fire scars are decomposing and burning. Although it has improved, there is inconsistent reporting across agencies and geographic areas. Heyerdahl et al.'s (1995) and Swetnam and Baisan's (1996) fire history databases each have a consistent, but different, structure.

We think that we need a more standardized approach to developing fire histories than has been done in the past. Useful approaches include standardizing fire frequency to the time period and amount of area sampled, and then comparing these among sites. Cross-dating is highly recommended and essential for aggregating across both spatial and temporal scales and for examining the role of climate. Fortunately, an increasing number of fire history data are cross-dated, but not all data are shared, nor thoughtfully targeted to address larger questions.
Temporal and spatial autocorrelation is a problem for sampling, but it is also an opportunity for understanding. Reed $(1994,1997)$ has developed statistical techniques that account for spatial autocorrelation in fire history data, but they are much more challenging to use than fire cycle (Johnson and Gutsell 1994) and other measures that do not account for spatial autocorrelation. Unbiased sampling of fire history specimens supports spatial analysis (Arno et al. 1993; Fulé et al. 1997; Heyerdahl 1997).

Databases need to be comprehensive enough to accommodate the many different kinds of data, for combining multiple types of data can increase the power and reliability of interpretations. This will also require an evaluation of the relative merits of the different data available. Other data together with information on data accuracy and limitations should be similarly available.

Integrated spatial databases can be used strategically to plan research. For instance, in the Southwest, new fire history sites are carefully targeted to add to the network of sites, thus ensuring an ability to compare fire history information not only through time but also across spatial scales.

\section{Multi-scale fire regime linkages}

Testing hypotheses about the linkages between fire, climate, vegetation, topography, and land use at multiple scales is crucial to improving our prediction capability and ecological understanding. Comparing among regions (e.g. Northwest, Southwest, Intermountain Region, and Sierras), within regions (across biophysical settings), and across time is a powerful way to understand the factors determining and constraining fire patterns (Swetnam et al. 1999; Rollins 2000; Rollins et al. 2001). This requires temporally explicit data. Further, we need to carefully design analyses to separate the influence of fuels, fire cause, humans, and climate on fire regimes. Fuel, topography, and weather are locally important, but climate influences and entrains fire patterns at regional and subregional scales (Swetnam and Betancourt 1998).

Whether fires increase or decrease spatial heterogeneity of vegetation is not well understood, and probably differs with fire regime (Agee 1998; Miller and Urban 1999) and with climate. Because spatial heterogeneity influences the spread of fires (Turner et al. 1994), it is likely that fires can maintain or enhance spatial heterogeneity, but the degree to which this happens and what controls it, are unknown.

Fire will respond to changes in climate, as it has in the past, but not all fire regimes will respond quickly (Baker 1995). Fire will be a catalyst for change in vegetation, perhaps prompting more rapid change than would be expected based on plant response to the changes in temperature and moisture availability. Thus fire may be more important than the direct effects of climate change on species fitness and migration (Weber and Flannigan 1997). Fires 
may be more frequent where climate warms (Overpeck et al. 1990; Kasischke et al. 1995; IPCC 1996; Goldammer and Price 1998), and fires may become more severe and more extensive as predicted for boreal forests (Weber and Flannigan 1997). There is consensus in the scientific community that humans have changed the global climate (IPCC 1996), but the changes in regional and local fire regimes are difficult to predict because they complicated by possible changes in ignition (e.g. lightning, Price and Rind 1994) and land use. In addition, we know little about the spatial and temporal relationships of lightning, fire and climate. There have been a few studies based on current lightning patterns (Flannigan and Wotton 1990; Granström 1993; Minnich et al. 1993; Fowler and Asleson 1994; Nash and Johnson 1996; Vázquez and Moreno 1998), but climate change is likely to affect lightning as well as the occurrence and effects of these fires (Price and Rind 1994).

\section{Fire regimes and fuels management}

Fuels management is based on the assumption that the abundance, type, and availability of fuels will change fire intensity, severity, and size. Often, frequency and intensity are inversely related which suggests that, when fuels accumulate as fires are excluded, the next fire will be more intense. However, research is needed to clarify the links between fire regimes and fuels. McKelvey and Busse (1996) and Keeley et al. (1999) analysed data on fire extent in southern California and concluded that fuels and fire suppression explained less about changes in fire regime through the 20th century than previous researchers (e.g. Minnich 1983) and managers had assumed. These studies and other hypothesis-driven research have rapidly advanced our knowledge.

Quantifying departures of current fire regimes from historical fire regimes is a way to evaluate ecosystem change and prioritize fuels management action, based upon the concept of historical or natural range of variability (Morgan et al. 1994; Landres et al. 1999). Management options may differ on those sites where wildland fire can be used readily now (those sites within the historical range of variability, HRV), from those where the only possibility is mechanical fuels management first (way outside HRV) and those where some combination of wildland fire use and prescribed fire will be most effective (those near but outside of HRV) (Landres et al. 1999).

Hardy et al. (1999) and Quigley and Arbelbide (1997) feel that the need for mechanical fuel reduction prior to reintroduction of fire increases once fires have been excluded from an area for at least twice the historical mean fire-free interval. In many dry forests dominated by longneedled pines, departures are often 4-8 times the historical mean fire-free interval.

Currently, most of the analysis of departure from historical fire regimes is based upon frequency. Although less frequent fires tend to be more both more intense and severe, evaluations of significant departures for ecological impacts must also consider fire size, spatial pattern and severity, whether severity is measured as mortality of overstory dominant vegetation, biomass consumed or by loss of soil nutrients.

\section{Conclusions}

Fire regime maps are useful in strategically planning both future management and research and for synthesizing what we know and highlighting gaps in that knowledge. When trends are available (e.g. from comparison of historical to current extent), they can be a powerful communication tool. In addition, such contrasts of past and present help us to evaluate and understand change. Careful analysis of the differences in trends from one place to the next can be very informative about the relative roles of land use, climate, vegetation, and topography and their complex interplay. In this way, the relative influence of land use and other human influences can be separated from the influence of climate and local site conditions. This is an example of how we could use what we know now to target research where we need the information or where we need to further refine what we know.

Fire has a profound influence on ecosystem structure, composition and function at temporal scales from years to decades and centuries, and from spatial scales from local to regional and continental. We are on the brink of understanding what determines and drives fire regimes and their change across scales. Because fire regimes may be very sensitive to our changing climate (Lenihan et al. 1998), this understanding will be crucial to managing fuels, fire risk, and ecological impacts of fires upon ecosystems now and in the future.

\section{Acknowledgements}

This material is based upon work supported by the National Science Foundation under Grants No. SBR-9619410 and SBR-9619410, and by the USDA Forest Service (INT94980-RJVA and INT-94913-RJVA). Comments from anonymous reviewers improved the manuscript.

\section{References}

Agee JK (1993) 'Fire ecology of Pacific Northwest forests.' (Island Press: Washington, D.C.) 493 pp.

Agee JK (1998) The landscape ecology of western fire regimes. Northwest Science 72(4), 24-34.

Albini FA (1976) Estimating wildfire behavior and effects. USDA Forest Service, Intermountain Forest and Range Experiment Station General Technical Report INT-30. Ogden, UT. 92 pp.

Arno SF, Petersen TD (1983) Variation in estimates of fire intervals: A closer look at fire history on the Bitterroot National Forest. USDA Forest Service, Intermountain Forest and Range Experiment Station Research Paper INT-301. Ogden, UT. 8 pp.

Arno SF, Reinhardt ED, Scott JH (1993) Forest structure and landscape patterns in the subalpine lodgepole pine type: a procedure for 
quantifying past and present conditions. USDA Forest Service, Intermountain Research Station General Technical Report INT-294. Ogden, UT.

Bailey RG (1995) 'Description of the ecoregions of the United States.' 2nd edn. USDA Forest Service Miscellaneous Publication 1391, Washington, D.C. 108 pp.

Baker WL (1995) Long-term response of disturbance landscapes to human intervention and global change. Landscape Ecology 10, $143-159$.

Barrett SW, Arno SF, Key CH (1991) Fire regimes of western larchlodgepole pine forests in Glacier National Park, Montana. Canadian Journal of Forest Research 21, 1711-1720.

Barrett SW, Arno SF, Menakis JP (1997) Fire episodes in the Inland Northwest (1540-1940) based on fire history data. USDA Forest Service, Intermountain Research Station General Technical Report INT-GTR-370. Ogden, UT. 17 pp.

Brown JK (1995) Fire regimes and their relevance to ecosystem management. In 'Proceedings of the Society of American Foresters Annual Meeting. Bethesda, MD'. pp. 171-178. (Society of American Foresters: Washington, D.C.)

Brown JK, Smith JK (Eds) (2000) Wildland fire in ecosystems: effects of fire on flora.: USDA Forest Service, Rocky Mountain Research Station General Technical Report RMRS-GTR-42, Volume 2. Ogden, UT. 257 pp.

Brown JK, Arno SF, Barrett SW, Menakis JP (1994) Comparing the prescribed natural fire program with presettlement fires in the Selway-Bitterroot Wilderness. International Journal of Wildland Fire 4, 157-168.

Chou YH, Minnich RA (1990) Spatial autocorrelation of wildfire distribution in the Idyllwild quadrangle, San Jacinto Mountain, California. Photogrammetric Engineering and Remote Sensing 56(11), 1507-1513.

Cissell JH, Swanson FJ, Weisberg PJ (1999) Landscape management using historical fire regimes: Blue River, Oregon. Ecological Applications 9(4), 1217-1231.

Clark JS (1988) Effect of climate change on fire regimes in northwestern Minnesota. Nature 334, 233-235.

Clark JS (1989) Ecological disturbance as a renewal process: theory and application to fire history. Oikos 56, 17-30.

Clark JS (1990) Patterns, causes, and theory of fire occurrence during the last $750 \mathrm{yr}$ in northwestern Minnesota. Ecological Monographs 60, 135-169.

Clark JS, Hussey T, Royall PD (1996) Presettlement analogs for Quaternary fire regimes in eastern North America. Journal of Paleolimnology 16, 79-96.

Conard SG, Wiese DR (1998) Management of fire regime, fuels and fire effects in southern California chapparal: lessons from the past and thoughts for the future. Tall Timbers Fire Ecology Conference Proceedings 20, 342-350.

Cook ER, Meko DM, Stahle DW, Cleaveland MK (1999) Drought reconstructions for the continental United States. Journal of Climate 12(4), 1145-1162.

Covington WW, Moore MM (1994) Southwestern ponderosa forest structure changes since Euro-American settlement. Journal of Forestry 92(1), 39-47.

Crutzen PJ, Goldammer JG (1993) 'Fire in the environment: the ecological, atmospheric, and climatic importance of vegetation fires.' (John Wiley and Sons: New York) 456 pp.

Cummins KL, Krider EP, Malone MD (1998) The U.S. national lightning detection network and applications of cloud-to-ground lightning data by electric power utilities. IEEE Transactions on Electromagnetic Compatibility 40(4), 465-480.

D'Elia J (1998) Using geographic information systems to examine fire ignition patterns and fire danger in the arid and semi-arid western United States. Thesis, University of Idaho. 242 pp.
DeLong SC (1998) Natural disturbance rate and patch size distribution of forests in northern British Columbia: Implications for forest management. Northwest Science 72, 35-48.

Dettinger MD, Cayan DR, Diaz HF, Meko DM (1998) North-south precipitation patterns in western North America on interannual-todecadal time scales. Journal of Climate 11(12), 3095-3111.

Finney MA (1995) The missing tail and other considerations for the use of fire history models. International Journal of Wildland Fire $\mathbf{5}$, 197-202.

Flannigan MD, Wotton BM (1990) Lightning-ignited forest fires in northwestern Ontario. Canadian Journal of Forest Research 21 , 277-287.

Fowler PM, Asleson DO (1994) The location of lightning-caused wildland fires, northern Idaho. Physical Geography 5, 240-252.

Frost CC (1995) Presettlement fire regimes in southeastern marshes, peatlands and swamps. Tall Timbers Fire Ecology Conference Proceedings 1, 39-60.

Frost CC (1998) Presettlement fire frequency regimes of the United States: A first approximation. Tall Timbers Fire Ecology Conference Proceedings 20, 70-81.

Fulé PZ, Covington WW, Moore MM (1997) Determining reference conditions for ecosystem management of southwestern ponderosa pine forests. Ecological Applications 7, 895-908.

Goldammer JG, Price C (1998) Potential impacts of climate change on fire regimes in the tropics based on MAGICC and a GISS GCMderived lightning model. Climatic Change 39, 273-296.

Granström A (1993) Spatial and temporal variation in lightning ignitions in Sweden. Journal of Vegetation Science 4(6), 737-744.

Green P (1998) Personal communication. Nez Perce National Forest, Grangeville, ID.

Grissino-Mayer HD, Swetnam TW (2000) Century-scale climate forcing of fire regimes in the American Southwest. The Holocene 10(2), 207-214.

Grissino-Mayer HD (1999) Modeling fire interval data from the American Southwest with the Weibull distribution. International Journal of Wildland Fire 9(1), 37-50.

Gruell GE, Schmidt WC, Arno SF, Reich WJ (1982) Seventy years of vegetative change in a managed ponderosa pine forest in western Montana- Implications for resource management. USDA Forest Service, Intermountain Research Station, General Technical Report INT-130. Ogden UT. 42 pp.

Habeck JR (1994) Using general land office records to assess forest succession in Ponderosa Pine/Douglas-fir forests in western Montana. Northwest Science 68(2), 69-78.

Hardy C, Burgan R, Saveland J, Ohlen D (1998a) Coarse-scale mapping of historic natural fire regimes, fire occurrence, current conditions, and wildland-urban interface for the conterminous United States. USDA Forest Service-U.S. Department of Interior Joint Fire Sciences Program; Boise, ID, work plan.

Hardy CC, Menakis JP, Long DG, Brown JK, Bunnell DL (1998b) Mapping historic fire regimes for the western United States: integrating remote sensing and biophysical data. In 'Proceedings of the 7 th biennial Forest Service remote sensing applications conference, 6-9 April 1998, Nassau Bay, TX'. pp.288-300. (American Society for Photogrammetry and Remote Sensing: Bethesda, MD)

Hardy CC, Bunnell DL, Menakis JP, Schmidt KM,. Long DG, Simmerman DG, Johnston CM (1999) Coarse-scale spatial data for wildland fire and fuel management. USDA Forest Service, Rocky Mountain Research Station, Fire Sciences Laboratory, November 1999. Online at: http://www.fs.fed.us/fire/fuelman,

Heinselman ML (1973) Fire in the virgin forests of the Boundary Waters Canoe Area, Minnesota. Quaternary Research 3, 329-382.

Heinselman ML (1978) Fire in wilderness ecosystems. In 'Wilderness management'. (Eds JC Hendee, GH Stanley and RC Lucas). USDA 
Forest Service Miscellaneous Publication No. 1365, pp. 249-278. Washington, DC.

Heinselman ML (1981) Fire intensity and frequency as factors in the distribution and structure of northern ecosystems. In. 'Fire regimes and ecosystem properties'. (Eds HA Mooney, JM Bonniksen, NL Christensen, JE Lotan and WA Reiners) pp. 7-57. USDA Forest Service General Technical Report WO-26. Washington, D.C.

Heyerdahl E (1997) Spatial and temporal variation in historical fire regimes in the Blue Mountains, Oregon and Washington: the influence of climate. Ph.D. Dissertation, University of Washington, Seattle.

Heyerdahl EK, Berry D,Agee JK (1995) Fire history database of the western United States. Environmental Protection Agency, Office of Research and Development: Report EPA/600/R-96/081. Washington, D.C:

Hunter ML Jr (1993) Natural fire regimes as spatial models for managing boreal forests. Biological Conservation 65, 115-120.

IPCC (Intergovernmental Panel on Climate Change) (1996) 'Climate change 1995 impacts, adaptations and mitigation of climate change: scientific-technical analyses.' (Cambridge University Press: Washington, D.C.)

Johnson EA (1992) 'Fire and vegetation dynamics: studies from the North American boreal forest.' (Cambridge University Press: New York) $129 \mathrm{pp}$.

Johnson EA, Gutsell SL (1994) Fire frequency models, methods, and interpretations. Advances in Ecological Research 35, 239-287.

Johnson EA, Larson CPS (1991) Climatically induced change in fire frequency in the southern Canadian Rockies. Ecology 72(1), 194201.

Johnson EA, Wowchuck DR (1993) Wildfires in the southern Canadian Rocky Mountains and their relationship to mid-tropospheric anomalies. Canadian Journal of Forest Research 23, 1213-1222.

Kasischke ES, Christensen N, Stocks BJ (1995) Fire, global warming and the carbon balance of the boreal forests. Ecological Applications 5, 437-451.

Keane RE, Arno SF, Brown JK, Tomback DF (1990) Modeling stand dynamics in whitebark pine (Pinus albicaulis) forests. Ecological Modelling 51, 73-95.

Keane RE, Long DG (1998) A comparison of coarse-scale fire-effects simulation strategies. Northwest Science 72, 76-90.

Keeley JE, Fotheringham CJ, Morais M (1999) Reexamining fire suppression impacts on brushland fire regimes. Science 284, 18291832.

Kitzberger T, Veblen TT (1997) Influences of humans and ENSO on fire history of Austrocedrus chilensis woodlands in northern Patagonia, Argentina. Ecoscience 4(4), 508-520.

Kitzberger T, Swetnam TW, Veblen TT (2001) Inter-hemispheric synchrony of forest fires and the El Niño-Southern Oscillation. Global Ecology and Biogeography 10(3), 315-326.

Kuchler AW (1964) Potential natural vegetation of the conterminous United States. American Geography Society, Special Publication No. 36.38 pp. +116 plates.

Landres PB, Morgan P, Swanson FJ (1999) Overview of the use of natural variability concepts in managing ecological systems. Ecological Applications 9(4), 1179-1188.

Lea SW, Morgan P (1993) Resprouting response of ninebark (Physocarpus malvaceus) shrubs to burning and clipping. Forest Ecology and Management 56(1993), 199-210.

Lenihan JM, Daly C, Bachelet D, Neilson RP (1998) Simulating broadscale fire severity in a dynamic global vegetation model. Northwest Science 72 (Special Issue), 91-103.

Lertzman K, Fall J, Dorner B (1998) Three kinds of heterogeneity in fire regimes: at the crossroads of fire history and landscape ecology. Northwest Science 72, 4-23.
Long DG (1998) Mapping historical fire regimes in northern Rocky Mountain landscapes. Thesis. University of Idaho, Moscow, Idaho. $63 \mathrm{pp}$.

Loveland TR, Merchant JW, Ohlen DO, Brown JF (1991) Development of a land-cover characteristics database for the conterminous U.S. Photogrammetric Engineering and Remote Sensing 57, 1435-1463.

Maciliwain C (1994) Western inferno provokes a lot of finger-pointing, but little action. Science 370, 585.

McKelvey KS, Busse KK (1996) Twentieth-century fire patterns on Forest Service lands. In 'Status of the Sierra Nevada, Volume II: Assessments and scientific basis for management options'. pp. 1119-1138. Sierra Nevada Ecosystem Project, Final Report to Congress. Wildland Resources Center Report No. 37. (Centers for Water and Wildland Resources: University of California Davis).

McKenzie D (1998) Fire, vegetation and scale: toward optimal models for the Pacific Northwest. Northwest Science 72, 49-65.

McKenzie D, Peterson DL, Agee JK (2000) Spatial variation in fire frequency in the Interior Columbia River Basin. Ecological Applications 10, 1497-1516

McKenzie D, Peterson DL, Alvarado E (1996a) Predicting the effect of fire on large-scale vegetation patterns in North America. USDA Forest Service, Pacific Northwest Research Station Research Paper PNW-RP-489. Portland, OR.

McKenzie D, Peterson DL, Alvarado E (1996b) Extrapolation problems in modeling fire effects at large spatial scales: A review. International Journal of Wildland Fire 6(4), 165-176.

Miller C, Urban DL (1999) Interactions between forest heterogeneity and surface fire regimes in the southern Sierra Nevada. Canadian Journal of Forest Research 29, 202-212.

Millspaugh SH, Whitlock C (1995) A 750-year fire history based on lake sediment records in central Yellowstone National Park, USA. The Holocene 5, 283-292.

Minnich RA (1983) Fire mosaics in southern California and northern Baja California. Science 219, 1287-1294.

Minnich RA, Vizcaino EF, Sosaramirez J, Chou YH (1993) Lightning detection rates and wildland fire in the mountains of Baja California, Mexico. Atmosfera 6(4), 235-253.

Minnich RA, Chou YH (1997) Wildland fire patch dynamics in the chaparral of southern California and northern Baja California. International Journal of Wildland Fire 7(3), 221-248.

Morgan P, Neuenschwander LF (1988) Shrub response to high and low severity burns following clearcutting in northern Idaho. Western Journal of Applied Forestry 3(1), 5-9.

Morgan P, Aplet GH, Haufler JB, Humphries HC, Moore MM, Wilson WD (1994) Historical range of variability: a useful tool for evaluating ecosystem change. Journal of Sustainable Forestry 2(1/2), 87-111.

Morgan P, Bunting SC, Black AE, Merrill T, Barrett S (1996) Fire regimes in the Interior Columbia River Basin: Past and present. Final Report for RJVA-INT-94913. On file at Fire Sciences Laboratory, USDA Forest Service, Rocky Mountain Research Station, Missoula, MT.

Nash CH, Johnson EA(1996) Synoptic climatology of lightning-caused forest fires in subalpine and boreal forests. Canadian Journal of Forest Research 26, 1859-1874.

Overpeck JT, Rind D, Goldberg R (1990) Climate-induced changes in forest disturbance and vegetation. Nature 343, 51-53.

Pickett STA, White PS (1985) 'Patch dynamics and natural disturbance regimes.' (Academic Press: New York) $472 \mathrm{pp.}$

Price C, Rind D (1994) The impact of a $2 \times \mathrm{CO}_{2}$ climate on lightningcaused fires. Journal of Climate 7, 1484-1494.

Quigley TM, Arbelbide SJ (Technical Editors) (1997) An assessment of ecosystem components in the interior Columbia Basin and portions of the Klamath and Great Basins.. USDA Forest Service, Pacific 
Northwest Research Station, General Technical Report PNW-GTR405. Portland, OR.

Reed WJ (1994) Estimating the historic probability of stand-replacing fire using the age-class distribution of undisturbed forest. Forest Science 40, 104-119.

Reed WJ (1997) Estimating historical forest-fire frequencies from time-since-last-fire-sample data. IMA Journal of Mathematics Applied in Medicine and Biology 14, 71-83.

Rollins MG (2000) Twentieth century fire patterns in the Gila/Aldo Leopold Wilderness Areas, New Mexico and the Selway-Bitterroot Wilderness Area in Idaho/Montana. Ph.D. Dissertation. On file at the Laboratory of Tree-Ring Research, The University of Arizona, Tucson, AZ. 184 pp.

Rollins MG, Swetnam TW, Morgan P (2001) Evaluating a century of fire patterns in two Rocky Mountain wilderness areas using digital fire atlases. Canadian Journal of Forest Research (In review.)

Ryan KC, Noste NV (1985) Evaluating prescribed fires. p. 230-238 In 'Proceedings, symposium and workshop on wilderness fire'. (Eds JE Lotan, BM Kilgore, WC Fischer and RM Mutch) USDA Forest Service, Intermountain Research Station General Technical Report INT-182. Ogden, UT.

Schmoldt DL, Peterson DL, Keane RE, Lenihan JM, McKenzie D, Weise DR, Sandberg DV (1999) Assessing the effects of fire disturbance on ecosystems: a scientific agenda for research and management. USDA Forest Service, Pacific Northwest Research Station General Technical Report PNW-455. Portland, OR.

Shinneman DJ, Baker WL (1997) Nonequilibrium dynamics between catastrophic disturbances and old-growth forests in ponderosa pine landscapes of the Black Hills. Conservation Biology 11, 12761288.

Simard AJ (1991) Fire severity, changing scales, and how things hang together. International Journal of Wildland Fire 1, 23-34.

Simard AJ, Haines DA, Main WA (1985) Relations between El Niño/ Southern Oscillation anomalies and wildland fire activity in the United States. Agricultural and Forest Meteorology 36, 93-104.

Skinner CN, Chang C (1996) Fire regimes, past and present. In 'Status of the Sierra Nevada. Vol. II: Assessments and scientific basis for management options. Sierra Nevada Ecosystem Project, Final Report to Congress. Wildland Resources Center Report No. 37, pp. 1041-1070.(Centers for Water and Wildland Resources, University of California: Davis)

Strauss D, Bednar L, Mees R (1989) Do one percent of forest fires cause ninety-nine percent of the damage? Forest Science 35(2), 319-328.
Swetnam TW(1993) Fire history and climate change in giant sequoia groves. Science 262, 885-889.

Swetnam TW, Baisan CH (1996) Historical fire regime patterns in the southwestern United States since AD 1700. In 'Proceedings of the 2nd La Mesa fire symposium, 29-31 March 1994, Los Alamos, New Mexico'. (Ed. CD Allen) pp. 11-32. USDA Forest Service, Rocky Mountain Research Station General Technical Report RMGTR-286. Fort Collins, CO.

Swetnam TW, Betancourt JL (1990) Fire-southern oscillation relations in the southwestern United States. Science 249, 1017-1020.

Swetnam TW, Betancourt JL (1998) Mesoscale disturbance and ecological response to decadal climatic variability in the American Southwest. Journal of Climate 11(12), 3128-3147.

Swetnam TW, Allen CD, Betancourt JL (1999) Applied historical ecology: using the past to manage for the future. Ecological Applications 9(4), 1189-1206.

Turner MG, Hargrove WW, Gardner RH, Romme WH (1994) Effects of fire on landscape heterogeneity in Yellowstone National Park, Wyoming. Journal of Vegetation Science 5, 731-742.

USDA Forest Service (1998) National Interagency Fire Management Integrated Database User's Guide. General Technical Report. USDA Forest Service, Washington, D.C.

Vázquez A, Moreno J (1998) Patterns of lightning- and people-caused fires in peninsular Spain. International Journal of Wildland Fire 8(2), 103-115.

Veblen TT, Kitzberger T, Villalba R, Donnegan J (1999) Fire history in northern Patagonia: The roles of humans and climatic variation. Ecological Monographs 69(1), 47-67.

Weber MG, Flannigan MD (1997) Canadian boreal forest ecosystem structure and function in a changing climate: impact on fire regimes. Environmental Review 5, 145-166.

Wein RW, Moore JM (1979) Fire history and recent fire rotation periods in the Nova Scotian Acadian Forest. Canadian Journal of Forest Research 9, 166-178.

Wells CG, Campbell RE, DeBano LF, Lewis CE, Frederiksen RL, Franklin EC, Froelich RC, Dunn PH (1979) Effects of fire on soil. A state-of-knowledge review. USDA Forest Service, Washington Office, General Technical Report W0-7. Washington, D.C.

White JD, Ryan KC, Key CC, Running SW (1996) Remote sensing of forest fire severity and vegetation recovery. International Journal of Wildland Fire 6(3), 125-136. 